\title{
God Taught Adam and Spoke to Moses: Language Origin, Functions and Early Multilingual Development
}

\author{
Aladdin Assaiqeli \\ English Language and Literature Department, Faculty of Languages and Communication \\ Sultan Idris Education University (UPSI), Tanjong Malim, Perak, Malaysia \\ E-mail: assaiqeli@fbk.upsi.edu.my
}

Received: August 3, 2019

Accepted: September 12, 2019 Published: October 8, 2019

doi:10.5296/ijl.v11i5.15206

URL: https://doi.org/10.5296/ijl.v11i5.15206

\begin{abstract}
This work addresses a number of crucial themes in the history of linguistic enquiry - themes that are still relevant today. Aiming to encourage multiple language learning, and give potential stakeholders momentum to provide supportive multilingual environments for children, the paper first addresses the question of the origins of language or the naturalism-conventionalism debate, highlighting children's innate potentiality for multilingual acquisition. Second, the paper highlights the pragmalinguistic functions of language, shedding light on the language-thought debate, and illustrating the centrality of language to our life, relations and the exercise of power. The paper, next, deals with the nature-nurture debate or the fantastic and prodigious potentiality of children to develop multicompetence in multiple languages with enviable unselfconscious ease. Drawing on records of longitudinal data comprising the linguistic development of three children raised as simultaneous bilinguals, the paper finally tackles the central theme of the study, providing evidence — both theoretical and empirical - that childhood multilingualism is not only legitimate and highly possible without any detriment of any kind, but also a great asset and a source of power; and that children who have the opportunity to expand their multilingual meaning potential from infancy or early childhood, and to maintain them throughout their lives are fortunate indeed; and therefore concludes that families and policymakers that can offer this critical opportunity to their offspring and citizens are highly encouraged to do so.
\end{abstract}

Keywords: Origin of language, Potentiality of learning, Language functions, Language acquisition, Competence, Bilingual development, Bilingualism, Multilingualism, Multicompetence, Simultaneous bilingualism, Sequential bilingualism, Meaning potential 


\section{Introduction}

Language is central to the essence of humankind and the purpose behind this unique creation. It is the prototypical resource for human articulate discourse and intelligence, thought and communication, power and often survival. Language is essential to human existence. It is also essential for fulfilling the purpose behind such existence. It is the primary faculty behind the supremacy and vicegerency of humankind on earth.

Man, when compared with many other creatures in the kingdom of animals or birds or even insects, pales into insignificance. Physically — in terms of strength or celerity or agility, for example - human beings are generally among the weakest of God's diverse creation.

Nonetheless, humankind have conquered, not only the Earth and tamed and harnessed the forces and resources of nature to their needs, but also gone into other spatial and temporal dimensions as to conquer and yield malleable other worlds. Humankind have been able to do this and far more, primarily through one extraordinary and unique human-specific faculty beyan or the potential for expression and articulate discourse.

Language is also the primary reason for the supremacy of mankind over the angels who do not have the free will and potentiality of learning associated with this faculty of reason and speech - unique to man. It is also the primary reason behind the qualification of this rational 'animal' to receive the divine message or trust (of reason and volition), and accordingly act as God's vicegerent on earth (see next section).

A meaning potential (Halliday, 1975) that is indefinitely expanding, language can be defined as a patterned socio-semiotic shared system of communication that comprises three levels: (1) phonology-graphology, (2) lexico-grammar, and (3) discourse-semantics; acquired and developed in the course or activity of languaging - interaction - and used to serve major pragmatic functions in human lives, to make sense of their experience, to help enact social processes and interpersonal relationships, carry out daily social functions and activities (Halliday \& Matthiessen, 2004), and fulfil the purpose of their creation.

A new language is an addition or expansion of this meaning potential, resulting in a multilingual meaning potential. A new language is "a new world of discourse" (Johnstone, 2002), a new way of exchanging acts of meaning, another system of "exploring new ways of being and acting" (ibid.), another way of thinking. "What language/s you speak is one way in which you immediately have access to, or excluded from, some kinds of power" (Thomas, Wareing, Singh, Peccei, Thornborrow \& Jones, 2004: 12), or in the words of Joseph Conrad, "Give me the right word and the right accent, and I will move the world" (Rozakis, 2003: 5).

Developing multilingualism is then like having multiple souls, multiple worlds, and multiple cultures. A different language is a different vision of life; and as the French proverb goes, "A man who knows two languages is worth two men." Speaking two languages enriches one's cognitive, conceptual and semantic capabilities (see below). Multilinguals who are proficient in two or more languages have been reported to have enhanced executive or brain function and even have reduced-risk for dementia (Bialystok, Craik, Grady, Chau, Ishii, Gunji, \& Pantev, 2005). 


\section{MInstitute ${ }^{\text {Macrothink }}$}

International Journal of Linguistics

ISSN 1948-5425

2019, Vol. 11, No. 5

This is a fact that makes language and the study of language of crucial and ever-increasing importance. This also implies that multilingual competence (Cook, 1992) is an asset - a fact that drives some adults to expand their meaning potential by adding or attempting to develop another language.

However, as anyone who tried to learn a language after puberty must have seen, learning a language after a certain age is far from easy. This is in sharp contrast with the enviable effortlessness and incredible unselfconscious ease with which children acquire this mammoth task. Indeed, not only is the child able to absorb with such facility the complex tristratal semiotic system of sound, form, and meaning of their environment without formal instruction, but also do so from zero and in a few years become a hero - a veritable chatterbox!

The child, despite this complexity of human language and the short span of time during which he or she accomplishes this incredible feat victoriously, proceeds in an unstoppable fashion to talk just as he/she proceeds to walk, constructing this abstract complex system implicitly — in a manner miraculous and wondrous.

All throughout life, language is indeed a marvelous phenomenon. It is the fabled magician's wand, the philosophers' stone, the elixir of life, and the cap of good fortune; it is "an alchemy that transmutes into material and social gain and advantage" (Kachru, 1986, quoted in Phillipson, 1992: 27); it is the charm that arrests hearts and intoxicates minds; it is the essential condition of knowing; it is a crucial means to upward social mobility and power. It is what ignites firestorms; it is what rules the world - symbolic power - not laws nor judges. Words are magic and we are mesmerized and ruled by such magic. Words shape our lives. Indeed, our life is not shaped by the event but by the meaning we attach to it - by the lexicogrammatical choices of our representation. Words can control objects, events, and people. Therefore, enriching one's meaning potential means enriching one's life in aspects and respects far-reaching and innumerable.

But despite such facility for language acquisition by children; and the undeniable merits of words and multicompetence (see also below); and the debunking by research of the myths surrounding multilingualism, there are still people who are concerned that "multilingualism puts children at risk" (McCabe, Tamis-LeMonda, Bornstein, Cates, Golinkoff, Hirsh-Pasek, Hoff, Kuchirko, Melzi, Mendelsohn, Paez, Song \& Guerra, 2013: 3).

There are still, for various reasons or fears, individuals, language teachers, and speech communities that argue against or are at least sceptical as whether the child should be exposed at an early age to more than one language simultaneously - the issue here is simultaneous bilingualism or multilingualism. This is not to mention linguistic chauvinists who view other languages as taboo or inferior and as such should be shunned rather than learnt and appreciated as a sign of God's omnipotence and absolute power (Quran, 30:22).

Harmful convictions of multilingualism then "still persist among many parents." They are divided as to whether the focus should be on L1 development first alone, and only after the child has mastered the system of rules of the first language (L1) can he or she be exposed to a second language (L2). Each side has its own speculations and reasons why simultaneous 
multilingualism or the simultaneous introduction of an L2 should or should not be institutionalized or encouraged. The reasons cited by each side — apart from certain stereotypes and myths - usually range from linguistic to cognitive and social to economic.

An argument for the divine origin of speech, and the pragmatic functions of language, in general, and advantageous expansion of one's meaning potential, in particular, this work is an attempt to show those against or sceptical of the effects of early or simultaneous multilingualism - especially in relation to innate preparedness, intellectual functions, cognitive development, creativity, conceptual and semantic development, language and literacy skills development, metalinguistic awareness, phonemic awareness, personality adjustment, academic achievement, and communication and analytic skills - that childhood multilingualism is legitimate and that children who have the opportunity to construct multiple languages from early childhood or infancy and to maintain them throughout their lives are fortunate indeed; and that thus multilingual families and policymakers that can offer this critical opportunity to their offspring and citizenry are highly encouraged to do so.

In this argument, not only does this paper provide theoretical evidence from relevant literature but also empirical evidence, by featuring records of longitudinal data comprising the linguistic development of three children raised as balanced simultaneous bilinguals. Such empirical data is aimed at supporting this proposition: the highly possible, cognitively beneficial and conceptually valuable introduction of early childhood multilingualism.

Within the context of this paper, this work is then a concise account of some significant aspects of human language, its divine origin, critical functions in human life, nature of acquisition, and childhood multilingualism, highlighting whenever possible the policy and practice implications of these issues for language learning and teaching, and language policy and planning. The rationale behind discussing these aspects of language is to encourage and stimulate interest in simultaneous multilingualism.

\section{Language Origin}

And when thy Lord said unto the angels: Lo! I am about to place a viceroy in the earth...

(Having brought him into existence,) God taught Adam the names, all of them. Then (in order to clarify the supremacy of humankind and the wisdom in their being created and made vicegerent on the earth), He presented them (the things and beings, whose names had been taught to Adam, with their names) to the angels, and said, "Now tell Me the names of these, if you are truthful (in your praising, worshipping, and sanctifying Me as My being God and Lord deserves). (Quran, 2:30-31)

Intelligence and articulation are human-specific. God created human beings and made them rational, having their mental abilities and linguistic abilities intertwined - a characteristic that sets them apart from all other creatures. This rationality constitutes the basis for the free will and so accountability here and in the Hereafter. If human beings were not rational, they would not have received any divine revelation and been instructed to act as vicegerents of 
God on earth, and therefore no day of judgement would have been awaiting them. The implication of this assumption is that the origin of language is divine.

We are meant to talk. The human being was created and programmed right from the start to speak, as this, as noted, would form the basis for the divine commandment or duty and vicegerency associated with this rational creation, both in terms of the reception of such divine communication and its propagation and dissemination over the years of this vicegerency on earth. This points to the divine origin of this faculty of speech with which the human beings have been endowed and distinguished since their creation. Indeed, as Chomsky (1994) puts it, "We are designed to walk... That we are taught to walk is impossible. And pretty much the same is true of language. Nobody is taught language. In fact, you can't prevent the child from learning it." We are born equipped with a meaning potential and the potentiality of learning.

Driven by the need to communicate to fulfil one's personal and social needs, along with the delivery of the divine trust (of reason and volition), this innate meaning potential drives the innate process of acquisition — the developmental process of constructing a system of communication.

Adam — being the first human being — had the gift of speech, endowed upon him directly by God. Allah taught him/bestowed upon him the knowledge and names of all things, and the potentiality of learning. He was equipped with a representational system (Saussure, 1916; cited in Thomas et al., 2004). God provided him with the "[innate] knowledge of the systematic correspondences between sound and meaning which make up our language" (ibid. p. 19). Allah taught Adam directly all signifiers - i.e. the names or labels - and their signifieds or concepts.

Adam was the first prophet of God, so he must have had the linguistic ability to communicate the message to his descendants. Adam's descendants have been genetically pre-wired to acquire language and other semiotic systems. Our brains have been designed and made ready to acquire semiosis or meaning-making systems. We are programmed to quickly acquire language upon exposure to linguistic data.

In this sense, preparedness for language is inspirational or divine rather than conventional or man-made. It is innate (Chomsky, 1965). It is divinely or genetically-endowed. The systems of rules children construct naturally are manifestations and effects of this endowed faculty of $\operatorname{logos}$ - of the innate meaning potential and the potentiality of learning.

The extraordinary productivity of human language, along with its systemicity and systematicity, and the effortless nature of the acquisition of such manifold complex systems by infants - a feature of the wondrous mind - entail or point towards a supreme designer. The capacity to learn or acquire language is "deeply ingrained in us as a species, just as the capacity to walk, to grasp objects, to recognize faces. We don't find any serious differences in children growing up in congested urban slums, in isolated mountain villages, or in privileged suburban villas" (Slobin, cited in Fromkin, Rodman \& Hyams, \& 2011: 324). 
The enviable bestowed potentiality of learning and meaning potential - this innate facility and creativity with which infants and children construct competence/multilingual competence - along with the speed and effortlessness with which they acquire the lexis and complex grammatical rules of language without any formal instruction, and the striking regularity and systematicity of the acquisition process across diverse languages and environmental circumstances are signs of this divine origin of language or this innate potential for meaning and expression.

Humankind were created for a purpose, and having beyan or the potential for expression and articulate discourse would be a precondition for receiving, believing or disbelieving in and communicating the divine message. Therefore, the human beings must have been created with the faculty of beyan or logos being part and parcel of their genetic and neurological make-up right from the start. The purpose of this life and our transitory existence in it is then to know (and worship) God - the Creator and Sustainer of this universe. Humankind, therefore, were created to and equipped with the ability to know.

Language is the instrument of knowing and learning. Without which, there is no way to comprehend reality. And so for this unique semiotic creation to know and worship God, language is essential, since it is the essential condition of knowing. Without this semiotic instrument, we cannot know. We cannot read the multiple signs of God in this universe. We cannot appreciate the multiple mechanisms that run like clockwork in our own bodies, nor can we appreciate the clockwork regularity observed in natural phenomena - such as the daily sunrise and sunset.

This further points to the divine origin of language - that we are meant or designed to mean. We are creatures who mean. We are equipped with the faculty of logos and the potentiality of learning with which or through which we can make a rational comprehension of the world inside and around us, understand our role in it, and communicate this role or purpose to the rest of humanity throughout our vicegerency in this world.

Furthermore, prophet-king Solomon could speak the language of birds. Allah states in the Quran (27:16):

Solomon succeeded David. He would say (citing in gratitude God's favours to him): "O people! We have been taught the language of birds, and we have been granted (some portion) of everything (which God provides for His servants). Surely this is a conspicuous favour".

So just like Adam was taught the names or signifiers of all things or their signifieds, so was Solomon taught the language of birds. It was bestowed upon him by God. No one throughout the history of humanity could communicate with birds. No one was taught the language of birds except this prophet/king. This is a further indication that the origination of language is divine - bestowed from high. 


\subsection{Language Diversification}

And among His signs is the creation of the heavens and the earth, and the diversity of your languages and colors. Surely in this are signs indeed for people who have knowledge (of the facts in creation, and who are free of prejudices) (30:22).

Over the years, the expanding environment of the descendants of Adam - sprawling human population - has served in the diversification of language, leading to polyglossia or the development of many dialects, which served in turn in a multiplicity of languages which are varieties of that first main lexifier language or common protolanguage Adam was taught whichever language that was - and from which all actual languages are descendants. This points to the monogenesis of language origin, that languages — these varieties — had originated from one source.

These linguistic varieties have evolved as human society expanded over the years, resulting in various speech communities. This conceptualization nullifies Condillac's past view that "all languages are descendants of the original language of gesture" — the language of nature (cited in Harris \& Taylor, 1989, Chapter 10). This theorization also questions all other speculations about the origins of speech such as the natural sound, social interaction, physical adaptation, tool-making, genetic change, etc. (Yule, 2010).

Our view also casts aside the Darwinian or 'evolutionary path' to language, moving from 'a pre-linguistic state of nature' (Harris \& Taylor, 1989:126) such as 'gestures' to 'physical adaptation' of the organs of speech, to a crucial genetic 'mutation', to 'grooming talking' to 'singing Neanderthals', to homo sapiens, to the kind of intelligent interlocutors we know today.

What we believe to have evolved instead is the multiplicity of dialects or languages as the social milieu or human society sprawled along the earth - not the language capacity or meaning potential itself. Human capacity for speech then has not evolved as such as this is a biological endowment, intertwined in the species humankind's genetic and neurological make-up. It is part of our creation and fashioning. It is the principal aspect of the human anatomy that sets us apart from all other creatures, and hence qualifies us to act as God's vicegerent or representative on earth. What has evolved, however as noted, is the variation in our languages, which the Quran speaks of as a sign of the Creator's power and omnipotence.

The biological make-up of the 'species man' is then universal, and the potential for meaning and expression has been concomitant with the creation of this unique 'species'. The language aptitude therefore has been the same and so is "man's reflective powers." The genesis of language and the mind, which are inseparable, is concurrent.

The gift of speech is then an endowment by God. In numerous verses that state facts about the human creation in the Quran, God always states the faculty of hearing as the first faculty to be endowed, followed by that of sight and then mind (intelligence and affections) - an indication to the role of speech in the fulfillment of the human being's divine message on earth as a viceroy or vicegerent (Quran, 16:78, 23:78, 67:23). 
This, rather than pointing to an evolutionary path, points to the existence of a language faculty since the creation of the first man. We were designed right from the start of the creation to talk just as we were designed to walk as observed by Chomsky. Adam spoke a language - as a form of direct revelation or inspiration - and what had happened later on was a diversification of that original inspired lexifier protolanguage. Language as thus has started with humankind; it was not a later invention or convention. It did not develop "in east Africa, around 100,000 years ago" (Aitchison, 1999:19) or between "100,000 and 50,000 years ago" (Yule, 2010:1) as some linguists speculate. Nor did it evolve from pre-historic pre-linguistic forms. The genesis of human speech was concurrent with the creation of the human being. It was not a later development or mutation or evolution or sophistication as imagined or hypothesized by some. The Quran declares — apodictically - that it was God who endowed the human being upon their creation with the faculty of beyan or gift of intelligence and articulate discourse:

\section{The All-Merciful}

has imparted this Quran [unto humankind].

He has created the human being:

He has imparted unto them articulate thought and speech (55:1-4).

This makes it clear that the creation of humans was synchronous with their ability of expression. This has to be the case because as we have already rationalized we, human begins, were not created for fun but rather for a purpose. Communicating this purpose effectively from one man, i.e., a messenger of God, has entailed the synchronous existence of a powerful medium of communication such as language or the linguistic faculty.

This account could help put an end to what has been described as "the hardest problem in science" - how language evolved? (Bickerton, 2009). The implication of this account, however, for policy and practice is to encourage simultaneous multilingualism as we are as discussed above - programmed for speech. We have been created to know and thus endowed with the potentiality of knowing and learning. We are meant to speak. We are made to articulate. We are "the articulate mammal." We are engineered to receive God's message and communicate it to others. The language organ is part of our being, part of our genetic wiring. We do not need to manufacture it or import it. It is there - just latent to be triggered and mushroomed by linguistic data from the environment. Our brains associate sound and meaning in definite ways — they are innately engineered to do so — and such sound-meaning associations result in the systems of rules that characterize each language (Chomsky, 1993). And so we do not struggle to speak as children. We just speak. We can't even prevent the child from speaking, which means that there are no difficulties or impediments to speech from the anatomical or mental point of view. On the contrary, we are all prepared and predisposed for the acquisition of meaning - quickly and effortlessly.

I wish to end this section on the origin and diversification of language with the following quote, taken from the exegetic interpretation of verse 4, Chapter 55 mentioned above $-\mathrm{He}$ has imparted unto humankind articulate thought and speech. 
Speech is a very complicated process, which takes place at the same instant as thought. Through speech, people make themselves known. How languages have come into being and been diversified is a mystery. No one knows how this happened, although there are many different theories [as noted]. However, God declares that He made all things [i.e. signifieds] known to Adam and taught him their names [i.e. signifiers] (2: 31). Therefore, language is also a direct gift from God (The Holy Qura'an: An eternal translation of the great book of the Universe).

\section{Language Functions}

This hardwired rational faculty of intelligence and articulate discourse is used and drawn upon for the exercise of an extraordinary range of personal, social, cognitive and devotional functions critical not only to communication and survival, socialization and acculturation, thought and sophistication, divine communion and enlightenment, liberation and emancipation, but also social control, power and domination. Every aspect of human life and relation is governed and enacted by language and languaging - by discourse.

Without language, human reason would have been deprived of its "principal instrument of expression" (Harris and Taylor (1989: 177), making this faculty central to the essence of human beings and the purpose behind their creation - which is to get to know (and worship) the Creator. Without language, thinking and articulating such thinking would be impossible. And so "When we study human language, we are approaching what some might call the 'human essence,' the distinctive qualities of mind that are, so far as we know, unique to man and that are inseparable from any critical phase of human existence, personal or social" (Chomsky, 2006: 88).

This articulate capacity or meaning potential is then what separates us from other beings. It "distinguishes humanity from all other living species, and it is logos or this naming potentiality to associate sound and meaning in definite ways which provides the basis for the Classical definition of the human being as the "rational animal"" (Harris \& Taylor, 1989: xi). It is clear, therefore, that it is language, this God-given faculty of beyan that has distinguished us, making us a unique creation.

It is the faculty of speech — this collective art of expression — that has thus made humankind articulate, and thus rational, intelligent and accountable; a thesis that makes language - in the language-thought debate - to precede thought or thinking, and so determine or at least affect it - the Whorfian notion or hypothesis that the structure of language determines (linguistic determinism) or affects (linguistic relativism) the structure of thought; or to use Badi and Tajdin's (2005) words: "I Speak, Therefore I think" (193).

Without this sophisticated conceptual and expressive intelligent apparatus endowed by God, human society would have been impossible. We would have never achieved "a rational comprehension of the world" in which we live and would have never been able to fulfill our role as God's representative on earth. Life and human society, in a word, would have been 
inconceivable as language is used to conduct and regulate the day-to-day transactions and activities that make up life - life is a constant flow of discourse.

In the course of a day, we use language for many purposes and functions. We use it referentially to transmit information and represent the world around us, i.e. to tell others what we know or how things work; we use it affectively to show our social status and what kind of relationship or power differentials between us and the addressee we have or wish to convey; we use it aesthetically to give us pleasure and titillate our imagination; we use it phatically as "social lubrication" to exchange pleasantries and indicate that we are willing to talk to one another and that we are pleased to see one another, and so on and so forth (Thomas et al., 2004).

Acquiring language then entails "mastering certain basic functions of language and developing a meaning potential for each" (Halliday, 1975, 2006: 53). Halliday talks about seven of these pragmatic functions evolved in the early years of acquisition and which are universal for children. These functions are (•) Instrumental - language used as a means of getting things done (one of the first to be evolved): the "I want" function; $(\bullet)$ Regulatory language used to regulate the behavior of others: the "do as I tell you" function; (•) Interactional - use of language in interaction between self and others: the "me and you" function; (•) Personal - awareness of language as a form of one's own identity: the "here I come" function; $(\bullet)$ Heuristic - language as a way of learning about things: the "tell me why" function; (•) Imagination - creation through language of a world of one's own making: the "let's pretend" function; $(\bullet)$ and Representational - means of expressing propositions, or communicating about something (one of the last to appear): the "I've got something to tell you" function (Halliday, 1975, cited in Saville-Troike, 2006: 53).

Language is also an instrument of power and social control. It is used to help human beings "construct and reconstruct reality" (Fairclough, 2003). It is a "way of behaving and making others behave" (Firth, quoted in Brown, 2000, 250). According to Michel Foucault, as phrased by Cameron, Frazer, Harvey, Rampton and Richardson, (1992), "the citizens of modern democracies are controlled less by naked violence or the economic power of the boss and the landlord than by the pronouncements of expert discourse" (cited in Jaworski \& Coupland, 1999: 141). The referential or ideational/representational function used to represent "the world around and inside us" (Halliday, 2004) and its affective impact which is "deeply tied up with power and social status" (Thomas et al., 2004) are two aspects or functions of language that are clearly associated with power and power relations.

Language influences our perception of people, events, objects, processes and phenomena. Our mental development, behaviours, beliefs and attitudes are shaped and constructed by language - by discourses. These are "conventional ways of talking that both create and are created by conventional ways of thinking" (Johnstone, 2002: 3). We become a member of a certain culture or professional group, or construct an identity through language. We encode in language or linguistic forms our mental picture of reality and how we account for our experience of the world (Simpson, 1993). We use it to enact forms of social (inter)action. We conceal, mitigate, produce or reproduce, legitimate or delegitimate a certain political event or a state of affairs or 
a social actor or even a whole people through language or a certain discourse (Simpson, 1993; Van Dijk, 1992, Fairclough, 2001, 2001b; Halliday 2004; Wodak and Myer, 2009; Amer, 2009).

Indeed, those who control symbolic production control us. Words can control objects, events, and people. The only way to construct a certain 'reality' and the only way we can understand such reality is through how it is represented to us discursively. We "manage our affairs by use of language. We use it to construct a social reality to suit our needs. The reality is only a convenience and we are constantly realigning its categories to accommodate changing circumstances, to make it more serviceable for our security and control" (Widdowson, 1992: 75).

Similarly, we use linguistic or discursive forms to enact and sustain ideology and hegemony; to brainwash and get brainwashed for war and violence; to stabilize or intensify social wrongs; to demonize a figure, a party, a people; to programme and become programmed to kill. Indeed, as found out in a study by Cohn (1987), the way how sane men of goodwill, i.e. defence intellectuals, "could think and act in ways that lead to what appear to be extremely irrational and immoral results (1)" is carried out through the medium of language.

Language is then a means of shaping thoughts and affecting perception, of constructing or transforming reality, of controlling cognition and drawing its responses, of shaping and managing the mind; of representing or delegitimizing a certain social actor or a people as "violent, confused and irresponsible" and legitimizing others as "peaceable, rational and flexible" (Amer, 2009: 26). Language as such does not only reflect but also construct or transform reality. In our dreams and visions, we also make use of language. We commune with God using language. "Language is also a primary vehicle through which adults socialize children, foster children's cognitive development, communicate information, and transmit the beliefs and values of their culture" (McCabe et al., 2013: 9).

Language is our instrument for thinking, uttering, informing, persuading, dissuading, entertaining, understanding, conceiving, perceiving, deceiving, indoctrinating, inspiring, writing, interpreting, analyzing, creating, enacting, establishing, acculturating, taming, ordering, subjecting, offering, concealing, mystifying, praising, condemning, seeking directions, worshipping, denying, promoting, officiating, making advances, 'making love,' divorcing, legitimating, incriminating, exasperating, exacerbating, hurting, bating, healing, supporting, refuting, defending, obscuring, mitigating, foregrounding, backgrounding, occupying, covering up, fabricating, equivocating, misleading, perpetuating the status quo, qualifying, disqualifying, formulating, apologizing, seeking permission, suggesting, fulfilling one's personal and social needs, etc.

In a nutshell, language dominates and permeates every aspect of human life and transaction. It shapes reality, our lives and relations. This is a fact that renders language and languaging, not only as a mighty weapon, but rather the mightiest, at the centre rather than periphery of human life — indeed "as something one cannot afford to neglect" (Amer, 2009: 26). 


\section{Language Acquisition}

If you've ever tried to learn a new language, you know it's not easy. There are new rules of grammar which come with many exceptions, new sounds that are hard to make, endless lists of vocabulary to commit to memory and so on. And yet, you managed to learn the basics of your very first language around the time you were two years old; no textbooks in sight (Khan Academy).

We do not know why exactly it is easy for children to acquire language so effortlessly. But what we are sure about - and what is relevant to this paper - is this effortless nature when it comes to age and age effects in language learning.

The earlier account about the origins of human language — from a scriptural perspective was meant to shed some light on this puzzle - the greatest feat every one of us is able to perform when we are still in short trousers.

Children are equipped with an innate template or blueprint for language. They are equipped with the potentiality for the construction of multiple grammars and lexicons. They have an enviable in-built capacity to develop competencelmulticompetence in whatever language or languages they get exposed to, and in a manner so rapid, so creative, so uniform, so systematic, so regular and indeed so easy compared with the mammoth task that they within a remarkably short span of time accomplish — victoriously! In the words of Aitchison (1999), "Human language is innately guided. Human infants are not only born speaking, but they know how to acquire any language to which they are exposed. They are drawn to the noises coming out of human mouths, and they instinctively know how to analyze speech sounds (19)."

When activated by linguistic data, this meaning potential results in the child having or developing a lexicon and a grammar for the language heard and used around them. This divine labelling insight or innate universal meaning potential for language acquisition also applies to the acquisition of multiple languages (see next section). In the words of Saville-Troike (2006), "L1 and L2 acquisition processes are similar in significant ways (46)." They both involve "creative mental processes;" they involve the "creative construction" of a grammar and a lexicon; they both involve "internally driven acquisition processes" (44); they are both "driven by inner forces in interaction with environmental factors" (41); they both follow generally predictable sequences (46).

This effortless and creative construction of lexicogrammar with its innate drive goes beyond the mere imitation, feedback and reinforcement advocated by the behaviourists. Imitation falls short to explain many novel utterances made by children; utterances that cannot have possibly been made by adults. In this context, I would like to cite some examples from my own first child - an example that defeats the behaviourist view or at best renders it insufficient an explanation for this internally-driven, divinely-designed creative acquisition process. 
Muhammad, at age $1 ; 11$, knowing how a spider looks like, once at the sight of my hairy chest, pointed to my chest, and much to my surprise and delight, he excitedly exclaimed, "Spider!" It is certain that this creative utterance about the hair of my chest, which to him, resembled the tiny and many feet (eight actually in number) of a spider could have never been made by any adult around him.

In another incident, I discovered that he used to refer to his carrycot as "ship," which indeed looked like a ship. No one had ever told him, of course, that that was a "ship," but he creatively thought of it as a "ship."

Yet, on a third occasion, at age $2 ; 10$, at the sight of a boat sailing in the vast deep, Muhammad jubilantly shouted, "The boat is swimming!" Now, his lexical choice "swimming," though inappropriate due to an age-induced vocabulary gap, is nonetheless creative and novel, which is one of the main points taken against the behaviourist view. Muhammad's lexical selection was creative and novel. It was creative in the sense that it served the communicative purpose; and novel in the sense that no adult had ever previously said that. Such novel utterances which defy "imitation;" such creative productions, frequently produced by children; this linguistic ingenuity and novelty on their part, render the behaviourist theory for language acquisition at best insufficient as noted.

Amr, my second child, at about the age of 3 made a unique utterance, one that could have never been made or imagined to be made by an adult. He came to me once while I was at home folding some tissues to keep in my pocket. He took one and wanted to imitate me children are wonderful imitators! They do not only copy what we say and how we say it, but also what we do and how we do it. I encouraged him and said, "You want to fold a tissue? Fold this one," introducing in my exchange the word 'fold' for the first time. He immediately set to work, and I kept encouraging him, repeating the word 'fold'. After sometime, I asked him about what he was doing, trying to elicit linguistic output from him. Much to my delight, he said, "Folding." He inflected the verb, using aspect - the grammatical category or system an adult would use in a similar situation.

By using the present continuous marker -ing, Amr was communicating to me an action in progress at the time of the utterance. Amr was certainly aware of the grammatical function of -ing being added to a verb in such a context. Joyous, I asked him again about what he was doing, and then the same structure was repeated. This indicated to me that Amr had reached a stage in his multilingual linguistic development where he had already grammaticalized that system, making it part of his developing grammar, which further meant that from that moment onward, aspect or the -ing system would be used automatically in such situations. Wishing to confirm my hypothesis or observation, I took Amr's hand and went on kissing it, asking him about what I was doing. Much to my joy, he said the expected — "Kissing!"

Exhilarated, I started nibbling at his little hand, while asking him to name that action. Now unlike the earlier two instances where he had promptly answered "folding," "kissing," this time he paused thoughtfully for a few seconds before saying something totally unexpected a cross lexico-grammatical synthesis of Arabic and English! He used the Arabic verb 
meaning "bite" - عض - suffixing it with the English aspectual inflectional morpheme -ing in a unique combination - an Arabic lexical item with English syntax!

Clearly, the child was aware of what he was doing. He was aware of the presence or working of two operating systems, operating simultaneously. He knew that the Arabic word he used in the English context was a borrowing he made to fulfil his communicative need. The thoughtful pause he made was an indication that he was looking for an "English" lexical item, but when he could not find - due to a semantic gap in his English system at the time - (see next section) he, with the characteristic creativity of the users of human language, resorted to another linguistic system where that word was available to him.

Such instances prove not only that it is not imitation that is at play when it comes to the way children acquire multiple languages, but also that they benefit from multilingualism in communicating their needs rather than keeping quiet.

Such examples also prove that children can construct multiple grammars and lexicons without confusing them, but rather using such linguistic resources to enhance their communication skills.

Drawing on these multilingual systems when communicating one's needs is seen not only as a sign of creativity on the part of the dual language child, but also a sign that the systems are evolving with a pace and level of achievement commensurate - besides age or cognitive maturation - with the child's level or quantity and quality of exposure to fluent language an important policy implication we are going to highlight later in this paper.

Children further have their own systematic reduced but progressively evolving intergrammars. So even "when children are trying to imitate what they hear, they are unable to produce sentences outside of the rules of their developing grammar" (Fromkin et. p. 326); and adult attempts at correction usually end up in a frustration for probably both, the adult and the child, as the child would keep repeating the utterance he or she uttered in the same way, being governed by his/her own developmental child grammar.

So, "child grammar is rule governed at every stage" (Aitchison, 1972, p. 153). An "example of the rule-governed nature of child language are forms such as mans, foots, gooses, which children produce frequently. Such plurals occur even when a child understands and responds correctly to the adult forms, men, feet, geese" (p. 154). "This is proof," Aitchison (1972) concludes "that a child's own rules of grammar are more important to him than mere imitation" (p. 154). Furthermore, "imitation," according to Fromkin and associates (2011) also:

fails to account for the fact that children who are unable to speak for neurological or physiological reasons are able to learn the language spoken to them and understand it. When they overcome their speech impairment, they immediately use the language for speaking (p. 326).

Language acquisition is then a developmental process driven not by imitation and reinforcement but rather by inner forces in interaction with environmental factors. Language 
is a biologically determined capacity endowed in the biological and neurological make-up of Adam and his descendants as noted. But this innate capacity cannot develop or blossom without nurture. It requires human interaction for it to be activated and set loose.

And so regarding the question whether language is 'natural' or not, we can "only conclude that it is natural for humans to have language" - that a human child has a natural not only propensity but also a setup for constructing the language which is used by the members of its family or the immediate environment around (Kreidler, 1998: 5).

This, however, as already noted, is not to belittle the role of the environment as it is the trigger whose presence is like water, metaphorically speaking, without which no seed can grow. The seed is there but it requires water to grow and blossom otherwise it will simply whither and eventually die (see the documented case of the child called Genie brought up in linguistic isolation, and of also feral children brought up in the wild by non-humans). And so we are born with full preparedness for language. But this divine latent potentiality that results in the effortless acquisition of multiple languages can be only activated and developed by sustained early high quality exposure to language in the early years of life (see next section).

This is unlike animals whose finite or limited systems of communication are genetically inbuilt and automatically ready for use, with or without the environment (Yule, 2010). There is no need for learning - a developmental process — or exposure. Human infants, however, require learning in an immersive linguistic environment. But that is all needed for this extremely complex system to emerge and evolve on its own. They are innately equipped by the potentiality of learning. Children below the critical period - that age beyond which this innate gift of implicit, effortless and swift acquisition begins to recede or dwindle, the period thought to be the age of puberty - do not require explicit instruction or external intervention in language (see below).

Whether born hearing or deaf, humans are then biologically prepared and equipped for language. And so arguments as to whether language is inborn or learnt are, in the words of Aitchison (2003) "futile:"

Both nature and nurture are important. Innate potentialities lay down the framework, and within this framework, there is wide variation depending on the environment. When individuals reach a crucial point in their maturation, they are biologically in a state of readiness for learning the behaviour. They would not learn at this time without a biological trigger and, conversely, the biological trigger could not be activated if there was no body around from whom they could learn the behaviour (133).

Resting his proposition of generative grammar and critique of the behaviouristic model upon "speed of acquisition," "poverty of data," and "language universals," Chomsky was amongst the first to highlight the innate preparedness for human language and its infinite potential.

The extraordinary complexity of human language and effortless nature of acquisition as noted earlier entail or point towards a supreme designer other than the environment. The potentiality of lingual acquisition is "deeply ingrained in us as a species" (Slobin, cited in 
Fromkin, Rodman \& Hyams, \& 2011: 324). Though complex, "very young children before the age of five - already" as stated by Fromkin and associates (2011:234) "know most of the intricate system that is the grammar of a language."

Before they can add $2+2$, children are conjoining sentences, asking questions, using appropriate pronouns, negating sentences, forming relative clauses, and inflecting verbs and nouns and in general have the creative capacity to produce and understand a limitless number of sentences (234).

Indeed, nothing can be thought of as more unique or wondrous than the little child's natural, pragmatic urge and extraordinary aptitude to capitalize on his or her "meaning potential" (Halliday, 1975) - the potential of "what can be meant" (124). In lucid, eloquent terms, Brown (2000) describes this divine capacity or natural urge of children to acquire language as follows:

As small babies, children babble and coo and cry and vocally or nonvocally send an extraordinary number of messages [which reflect the sounds of all the languages of the world]. As they reach the end of their first year, children make specific attempts to imitate words and speech sounds they hear around them, and about this time they utter their first "words" [the holophrastic or "whole phrase" stage]. By about 18 months of age, these words have multiplied considerably and are beginning to appear in two-word and three word "sentences" [the telegraphic stage] such as [...] "bye-bye Daddy," "gimme toy," ["nice music?," "Daddy, more (r)oach here!"] and so forth. The production tempo now begins to increase [...]. By about age three, children can comprehend an incredible quantity of linguistic input; their speech capacity mushrooms as they become the generators of nonstop chattering and incessant conversation [...] (21) [For further actual genuine instances of such child language, see tables below]!

This prodigious meaning potential which starts with cooing and gurgling, progressing into the active construction of semiotic systems, Brown (2000) further states, "continues into school age as children internalize increasingly complex structures, expand their vocabulary, and sharpen communicative skills" (21). Here, at school age, young children not only continue in the same effortless fashion to learn language and learn through language but also learn about language. In other words, children at school age begin to learn what to say and what not to say - pragmatic competence - as part of their expanding communicative competence or ability of expression. Such construction of competence is a consequence or side effect of the activation of their meaning potential - and exposure.

Children are also motivated in their divinely programmed construction and proliferation of grammars by the social value of speech which they recognize at an early age. The early realization by infants that noises or sounds is what can help those around to pay attention to their needs drives them further to engage in languaging to satisfy such needs and in so doing develop the pragmalinguistic functions associated with language acquisition. Hallidayan 
linguistics has played a major role in bringing this functional view of language - where language is used to serve major functions in human life - to the fore.

Language acquisition is then the product of and interplay between social interaction (nurture) and cognitive development/maturation (nature); "a product of both the mind and the social contexts in which it is used". Language has its incubator or basis in the mind but is triggered and developed in contexts of social interaction. "Language is a social construct as much as it is a mental ability." It is a cognitive phenomenon (involving the mind and brain), and a social phenomenon (reflecting and indeed reinforcing structures in society).

\section{Multilingualism}

I speak Spanish to God, Italian to women, French to men and German to my horse.

(Holy Roman Emperor Charles V)

One of the main implications of the above discussion on the origins of language, its pragmatic functions and centrality to human life and relations, power and control, prestige and success is to stimulate interest in multilingualism among families and communities that can afford such opportunity - raising their children or citizens as multilingual speakers with multiple languages from an early age. This has been proven possible and achievable under the right circumstances. According to Lightbown and Spada (1999):

There is a considerable body of research on the ability of young children to learn more than one language in their earliest years. The evidence suggests that, when simultaneous bilinguals are in contact with both languages in a variety of settings, there is every reason to expect that they will progress in their development of both languages at a rate and in a manner which are not different from those of monolingual children.

Lightbown and Spada (1999) come to the conclusion that children who have the chance to learn or be exposed to multiple languages "from early childhood and to maintain them throughout their lives are fortunate indeed, and families that can offer this opportunity to their children should be encouraged to do so" (4).

Young children have the aptitude to acquire their native languages (L1 or L1s) with ease and invariant success. Crystal (2003) asserts that "young children acquire more than one language with unselfconscious ease" (11). This unselfconscious ease and this unique aptitude of young children for acquiring language within a remarkably short time are indeed enviable. This becomes, as noted, even more enviable when children who are exposed to multiple languages can develop multilingual competence with the same ease and success. According to Crystal (ibid.), "children are born ready for bilingualism". He adduces that "some two-thirds of the children on earth grow up in a bilingual environment, and develop competence in it" (p. 17). McCabe and colleagues (2013: 3) state that "multilingualism is an international fact of life, with roughly $2 / 3$ of the world's population estimated to understand and speak two or more languages (Dörnyei \& Csizer, 2002).” 
Biologically, children are ready for languaging and the construction of multiple meaning-making systems. The global village in which we live in nowadays with its diverse media, multimedia technologies and communication facilitates exposure to a second or third language. All that is left is the right attitude and a capitalization on this meaning potential of the young by multilingual parents, language teachers, child professionals and policy-makers.

Despite this prevalence of multilingualism in the world, there are still as noted in the introduction individuals who have negative perceptions of multilingualism. One misconception of over a hundred years of literature on bilingualism is that children's intelligence will suffer if they are bilingual. This misconception as noted lasted unfortunately for about a century. It wasn't until the 1960s that studies began to dispel such negative conceptions and to report positive cognitive effects of multilingualism.

But again despite such studies that associate multilingualism with more brain growth and mental management, better concentration, better consolidation of information and problem-solving, metalinguistic awareness, creativity, brain development (Diaz, 1985), "increased metacognitive and metalinguistic skills" (Bialystok, 2007), "high academic achievement and positive personality adjustment" (McCabe et al., 2013), creativity, phonemic awareness, and is related to greater conceptual and cognitive flexibility in life, the notion that multilinguals "may have a lower IQ still exists among many people, particularly monolinguals."

I personally have met people who hold such negative or unfavourable perceptions of bilingualism, including language teachers. They have this fear that the introduction of a second language in the education system will impact negatively on the intelligence of the child and the development of their heritage language.

They see translanguaging or code-switching as a sign of confusion (see below) on the part of the child. They think that such bilingual approaches can only produce ersatz speakers rather than real bilinguals.

Reality, however, is that such perceptions are wrong and based on unfair studies conducted under unfair circumstances. The bilingual children who were tested, for example, did not come from the same social class or that the test was given in the weaker or less developed language of the child.

The current perception about multilingual children is that, where two linguistic systems are relatively well developed, bilinguals have distinct cognitive advantages over monolinguals. There is a large body of research that suggests that:

being multilingual fosters children's ability to think about language per se, leading to increased metacognitive and metalinguistic skills (Bialystok, 2007). Recent brain research indicates that multilinguals have greater brain tissue density in the areas of the brain related to language, memory, and attention, with the highest levels of tissue density among those who were exposed to a second language prior to age 5 (Mechelli et al., 2004) (ibid.). 
Language and the brain are intimately connected. Specific areas of the brain are localized or devoted to language. Linguistic stimuli can activate more cells in the brain. Vice versa, brain development is tied to early and sustained or regular exposure to language. In the words of Kreidler (1998):

Our ability to use language and our ability to think and conceptualize, develop at the same time and these abilities depend on each other. So, while we may retain some memory of learning to read and write, which we began around the age of six, we do not remember learning to understand what was spoken to us in the first four or five years of life and still less our struggles to speak (6).

As a way to encourage potential stakeholders - i.e., policy makers, language educators, language teachers and families who can provide a bilingual/multilingual environment for their children - following are six tables that feature utterances of three multilingual children who have been exposed to two linguistic systems right from birth, thus constructing simultaneously two distinct lexicons and grammars. They are also currently being exposed to Malay. The utterances were collected longitudinally.

These children are Muhammad, born in June 2006, Amr, born in March 2011, and Joury, born in February 2017. The chief source of the two lexicogrammatical systems they are constructing/have constructed, Arabic and English, is their parents: their mother being the primary source of Arabic; and their father - who is not a native speaker of English but a proficient ESL/ELT professional — the chief source of English.

The tables are meant to favour and encourage early simultaneous multilingualism, as an opportunity to help our young ones benefit from the positive cognitive, social and professional advantages of developing multicompetence; of bringing them up with more than one "native" language right from infancy.

Along with the theoretical evidence provided, these tables are meant to encourage, amongst others, parents and English language teachers who are against or hesitant or have negative thoughts or misconceptions or even those who have not thought of such issue - raise their children as simultaneous multilinguals.

If a parent is proficient in a language, e.g. English, "then early exposure to such proficient English is beneficial" (Kovelman et al., 2008, cited in McCabe et al., 2013: 9). If one parent is proficient in English and another in Arabic, for instance, infants will develop multicompetence, showing fluent acquisition of both English and Arabic. Multilingual children "develop separate, but related, linguistic systems, allowing them to learn a new language without interfering with the development of the first" (McCabe et al., 2013:9).

This argument is also meant to encourage FL/L2 teachers to introduce language orally in their classrooms as such exposure would help pre-school and school children acquire language and develop oracy - the ability to express oneself fluently and grammatically in speech. 
Table 1. Simultaneous early multilingualism: sample of Muhammad's acquisition of English by Age 2: A corpus of longitudinal data based on a parental diary of speech development

\begin{tabular}{|c|c|c|c|c|c|c|c|}
\hline Nouns & Nouns & Nouns & Nouns & Nouns & Verbs & Adj & $\begin{array}{l}\text { Holophrases/ } \\
\text { Telegraphese }\end{array}$ \\
\hline hose & Quran (when & salad & Cola & car key & give & hot & Up \\
\hline bear & seen or heard) & juice & shower & football & take & smart & Dry your face. \\
\hline kiss & car & cake & horse & airplane & sleep & tasty & Shake my hand. \\
\hline clock & cat & bike & socks & prayer mat & eat & sour & How are you? \\
\hline watch & donkey & sea & shoes & ice cream & drink & & Speak to the parrot. \\
\hline sheikh & monkey & (tooth) pick & purse & eyebrows & open & & Give him a kiss. \\
\hline lemon & cow & shovel & money & earlobe & come & & Put it in the bin. \\
\hline (lemon) & ball & balloon & button & (pea) nuts & pray & & Sit down! \\
\hline lion & skip & macaroni & glass & corn flakes & wait & & Stand up! \\
\hline switch & pen & mortadella & tea & wind chimes & wake up & & Go down! \\
\hline belt & pencil & gun & towel & candle & throw & & Go up! \\
\hline peg & clip & swing & coffee & comb & want & & Close (the door) \\
\hline hanger & spoon & racket & rice & gum & spray & & Turn on/off \\
\hline hair & fork & milk & onion & window & (perfume) & & Bring me... \\
\hline cheek & table & truck & pepper & shorts & dress up & & Bring the shoes to \\
\hline chest & glasses & mouth & banana & ship & put on & & Kill the roach. \\
\hline tummy & orange & goat & knee & giraffe & & & Look at... \\
\hline nipple & kiwi & rabbit & fart & teeth & & & some more (of \\
\hline ass/ butt & bread & snake & circle & brush & & & something) \\
\hline phone/ & soup & nose & bottle & loofah & & & Take off your \\
\hline telephone & soap & bed & scissors & incense & & & socks/shoes \\
\hline piano & shampoo & pip & bird & cough & & & Give the bottle/ \\
\hline duck & hand & hat & pillow & ankle & & & stapler etc. to... \\
\hline goose & ear & elephant & cushion & laptop & & & Where is... \\
\hline jeep & head & sun & tap & honey rosary & & & Put it back... \\
\hline moon & face & spit & receiver & kitchen & & & Come here! \\
\hline perfume & shoulder (s) & disc & lid & chips & & & No \\
\hline lips & foot & cracker & flower & cucumber & & & Go out! \\
\hline eye & fingers & saucer & tree & door & & & Bye! \\
\hline singlet & toes & pants & stapler & T.V. & & & Bravo! \\
\hline diaper & tissue & underpants & chicken & A.C. & & & Wow! \\
\hline cock & plate & shirt & meat & water & & & Of course \\
\hline balls & flag & tie & fish & wheel & & & Use your right hand. \\
\hline light & cassette & suds & chair & battery & & & Shoot the man \\
\hline sky & parrot & corner & stool & date & & & Good morning! \\
\hline neck & box & blender & enough & $\operatorname{dog}$ & & & Bye! See you! \\
\hline basket & $\operatorname{man}$ & garbage & spider & pin & & & All right! \\
\hline $\cot$ & woman & clothes & pocket & music & & & Let go! \\
\hline
\end{tabular}




\section{Macrothink}

International Journal of Linguistics

ISSN 1948-5425

2019, Vol. 11, No. 5

Table 1 above shows a sample of Muhammad's construction of the English lexis and grammar by the age of 2 . The first five columns present the word class of nouns. The sixth column presents verbs, while the sevenths the class of adjectives, and the last, holophrastic and telegraphic constructions, respectively.

Now we are going to take a look at a sample of Muhammad's simultaneous acquisition of Arabic lexis and grammar by the same age.

Table 2. Simultaneous early childhood multilingualism: Sample of Muhammad's acquisition of Arabic by Age 2

\begin{tabular}{|c|c|c|c|}
\hline الجمل/الأفعال & الأسماء & الأسماء & الأسماء \\
\hline سكر(الباب_الثلاجة) & جر افة & طيارة & فلفل \\
\hline افتح(الباب_الثلاجة) & تخت & سيارة & دبوس \\
\hline هاتى (تفاحة_ موز) & ش الشاورما & ثلاجة & قلم \\
\hline تعال & أحبك & حمام & ساعة \\
\hline بدى (أكل) & تيته & ماء & صورة \\
\hline بديش & سيدو & لحمه & فتوش \\
\hline ن ن & بالون ب & تفاحة & عصفور \\
\hline كمان(عصير - ماء) & أيدك & موز & قثاطه \\
\hline أعطيني & رجلك & صابون & معلقة(ملعقة) \\
\hline طعينى & شاطر & بوسه & سكين \\
\hline أكل & كورن فليكس & عصير & زعتر \\
\hline 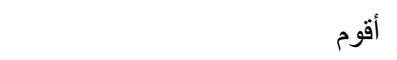 & حليب & سكر & حلوة \\
\hline أقعد & برفان(عطر) & علكه & فر اشة \\
\hline ألبس أل & كلوت & شاي & قداحة \\
\hline أشلح & ل لبن & كاسه & مقص \\
\hline وقعتيها & & فلافل & عينك \\
\hline بره & & صر اصير & رأس \\
\hline يله & & & مربى \\
\hline خلص & & & \\
\hline توجع & & & \\
\hline غسل أديك & & & \\
\hline
\end{tabular}

The first three columns present samples of the word class of nouns. The final column presents verbs, and holophrastic and telegraphic constructions - some of which are actually sentences in Arabic - that underlie an emerging grammar. Such signs of an emerging developing grammar can also be seen in English - the last column in Table (1), Table (3) and Table (5), respectively where utterances such as "Up," "Away," "Out," "More," etc. are an expression of a whole idea being expressed in a single word. This stage was followed by telegraphese where an utterance consisted of a number of content words but without function words as in "Daddy up," or "Daddy play" or "The book down," in messages similar to these of a telegraph, hence is the term telegraphese. 
Now we are going to look at a sample of the multilingual construction of Amr (b. 2011) the second bilingual child raised under the same circumstances.

Table 3. Simultaneous early childhood multilingualism: Sample of Amr's acquisition of English by Age 2: 3

\begin{tabular}{|c|c|c|c|c|c|c|c|}
\hline Nouns & Nouns & Nouns & Nouns & Nouns & Adj & Verbs & $\begin{array}{l}\text { Pronouns/Adverbs/ } \\
\text { Holophrases/Telegraphese }\end{array}$ \\
\hline Daddy & spoon & garden & cap & machine gun & nice & come & Down (as in go down, fell \\
\hline baby & knife & $\operatorname{man}$ & bed & breakfast & dark & go & Down, etc.) \\
\hline cat & fly & cheek & photo & cupboard & empty & kiss & Ok \\
\hline car & candy & chin & wallet & car key & dead & sit down & Up \\
\hline cow & coffee & bee & (r)osary & wee-wee & dirty & take & $\mathrm{Me}$ \\
\hline cup & eye & jam & apple & rock candy & hot & put & Daddy come \\
\hline nut & bus & broom & card & corn flakes & cold & sleep & Phone up (on the desk) \\
\hline fire & work & sea & comb & stick & wet & wait & Back \\
\hline fan & birdie & (r)ubber & TV & plate & gone & pray & The book down \\
\hline hat & bird & fridge & pain & (1)aptop & walk & kill & The boy sleep \\
\hline bin & clippers & book & mat & pants & broken & fishin & Here \\
\hline bike & shorts & paper & drawer & kiss & sick & (finish) & What's this? \\
\hline horse & pillow & pencil & neck & haircut & & work & This \\
\hline ear & kite & nappy & glasses & insect & & eat & Let go! \\
\hline nose & cartoon & (dino)saur & shop & cloth & & sit & Keep it. \\
\hline mouth & pocket & (cu)cumber & grocery & hammer & & keep & one \\
\hline teeth & mannie & fish & $\operatorname{sink}$ & & & cut & two \\
\hline head & honey & medicine & tissue & box & & (woke)n up & three \\
\hline hair & water & milk & soap & shampoo & & broke & Wash it (an apple) \\
\hline marble & glass & money & flower & e(le)phant & & fix & More \\
\hline ball & park & deer & belt & nap & & clean & Out \\
\hline door & carpet & goose & cushion & perfume & & & Enough \\
\hline fart & (r)oach & banana & chilli & window & & & My book \\
\hline tiger & chicken & watch & cake & (mobile) & & & Away \\
\hline hand & music & ant & light & phone & & & Nice music? \\
\hline chair & (r)ubbish & bi(s)cuit & sandals & (screw) driver & & & Daddy, more (r)oach here, \\
\hline shoes & shirt & fingers & pigeon & (sea) shell & & & Home! \\
\hline pepper & glass & toilet & toy & (s)chool & & & Cut (while holding a card \\
\hline pen & (pane) & towel & sun & coaster & & & and a pair of scissors) \\
\hline kiss & knee & navel & moon & mosque & & & Music, Maher Zain; come. \\
\hline ass & bag & buckle & gum & cup & & & Walk here. \\
\hline tummy & shower & (y)oghurt & nail & home & & & This one... \\
\hline boy & swing & & pain & uncle & & & Mummy bought cup \\
\hline
\end{tabular}




\section{Macrothink}

International Journal of Linguistics

ISSN 1948-5425

2019, Vol. 11, No. 5

Table 3 above shows a sample of Amr's construction of English lexicogrammar. The next table - Table 4 below - shows a sample of Amr's simultaneous construction of the Arabic system, along with English.

Table 4. Simultaneous early childhood multilingualism: Sample of Amr's acquisition of Arabic by Age 2:3

\begin{tabular}{|c|c|c|c|c|c|}
\hline الجمل/الأفعال & الصفات & الأسماء & الأسماء & الأسماء & الأسماء \\
\hline خليها & سخنه & تفاحة & كتاب & شنته(سنطة) & 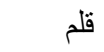 \\
\hline بديش & حرام ل & طقية & كهربة & حصان & ماما \\
\hline جييو & شاطر & بوسة ب & ريموت & زجاج & كرتون \\
\hline صب & حلو & انف & قهوة & 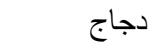 & حمار \\
\hline رميتو & & ضو & 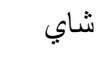 & مشط & مخدة \\
\hline لقيتوته (وجدته) & & صوى (صرصور) & 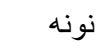 & شيبس & فوق \\
\hline كب & & حبيبي & حمص & (مف) تاح & كلب \\
\hline (ضربني)كف & & ككه & هذا & كمبيوتر & بابوج ل \\
\hline خلص & & باب & 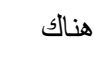 & دده & ريحة \\
\hline بح & & يدي & 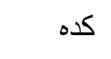 & كو لا & كاسة \\
\hline فن & & كعكة & فول & واوا & كمان \\
\hline صحي(استيقظ) & & سها & مبه & دم & تانى \\
\hline بحبه & & صحن & حمام & مرجيحه & أنا \\
\hline طيب ماما & & ملعقة & سكين & بوظة & بتول \\
\hline \multirow[t]{4}{*}{ تعتي } & & مها & شوكة & حليب & تفاحة \\
\hline & & نور & كرسي & 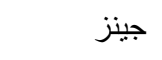 & موز \\
\hline & & & سكر & محمد & صابون \\
\hline & & & عصير & ت تلفزيون & بوسه \\
\hline
\end{tabular}

From right to left, the first four columns present samples of the word class of nouns. The fifth column presents a sample of adjectives; and the final column presents verbs and larger grammatical constructions some of which amount to complete sentences.

Children as noted are divinely programmed for speech. All that is needed for such innately-driven process — the effortless building and expansion of the child's meaning potential - is sustained exposure to languaging.

Now we are going to take a look at the multilingual acquisition of Joury (b. 2017) - my third bilingual child raised under the same circumstances where she has been exposed to English and Arabic. Following then is a sample of Joury's early multilingual development of the English and Arabic languages.

It must be emphasized that these are only samples because the actual linguistic acquisition goes far beyond what these samples show. What is being constructed - simultaneously are two language systems with all their complex three-level components: phonology at one edge, semantics and at the other end, with lexicogrammar as intermediary. 


\section{Macrothink}

International Journal of Linguistics

ISSN 1948-5425

2019, Vol. 11, No. 5

Table 5. Simultaneous early childhood multilingualism: Sample of Joury's acquisition of English by Age 2:6: A corpus of longitudinal data based on a parental diary of speech development

\begin{tabular}{|c|c|c|c|c|c|c|}
\hline Nouns & Nouns & Nouns & Nouns & Verbs & Adj & $\begin{array}{l}\text { Pronouns/Adverbs/ } \\
\text { Holophrases/Telegraphese }\end{array}$ \\
\hline daddy & hand & stool & Quran & move & cold & $\mathrm{Me}$ \\
\hline car & cat & chair & bangle & draw & hot & There (while pointing) \\
\hline apple & hat & cup & lemon & play & yummy & Wow! \\
\hline boy & $\operatorname{dog}$ & pen & egg & eat & bad & $\mathrm{Hi} !$ \\
\hline ball & lollipop & cards & tree & drink & & Light (turn on the light) \\
\hline toy & milk & table & ant & go & & Bike (I wanna a ride on \\
\hline date & TV & bangle & fish & come & & the bike) \\
\hline wee wee & feet & towel & spoon & give & & More \\
\hline eye & home & a box of & fridge & get & & Up (let's go up/I wanna \\
\hline light & house & tissues & coffee & take & & Go up/or it's up) \\
\hline Blippi & swing & mobile & drink & clean & & Bravo! \\
\hline bike & bikkie & phone & sleep & put & & Out \\
\hline yes & kiss & playground & perfume & sit & & Open your mouth! \\
\hline no & kitchen & Amr (her & comb & & & Close your eyes \\
\hline mama & shoes & brother) & pocket & & & Bye! \\
\hline uncle & dress & remote & toilet & & & Bye bye! \\
\hline knee & underpants & control & kitchen & & & Shake hand \\
\hline bird & bed & prayer mat & watch & & & Give me a kiss \\
\hline birdie & juice & playground & water & & & Get me $(\ldots)$ \\
\hline fan & door & remote & orange & & & Where (is...)? \\
\hline baby & chicken & control & ass & & & Daddy play (Daddy, let's \\
\hline (ba)nana & rice & spoon & song & & & play) \\
\hline key & ice cream & nuts & soup & & & \\
\hline elbow & dustbin & bag & nose & & & \\
\hline pebble & candy & pepper & head & & & \\
\hline ear & bag & fork & elephant & & & \\
\hline hair & money & (coco)nut & duck & & & \\
\hline lion & football & water & horse & & & \\
\hline onion & choccy & table & zebra & & & \\
\hline tea & book & uncle & shoulder & & & \\
\hline blocks & tongue & window & bun & & & \\
\hline sheep & tissue & monkey & socks & & & \\
\hline rabbit & slippers & bottle & toes & & & \\
\hline grapes & rosary & bone & back & & & \\
\hline glue & butterfly & & pillow & & & \\
\hline tea & ice cream & & & & & \\
\hline
\end{tabular}


Table 5 above shows Joury's construction of the English lexis and grammar by the age of 2:6. Joury has the same level of acquisition and linguistic development in the Arabic language (see Table 6 below for a sample).

Table 6. Simultaneous early childhood multilingualism: Sample of Joury's lexicogrammatical acquisition of Arabic by Age 2:6

\begin{tabular}{|c|c|c|c|c|}
\hline الجمل/الأفعال & الأسماء & الأسماء & الأسماء & الأسماء \\
\hline بدك & دو دو & دفتر & باب & ماما \\
\hline فنى & عمو & ريموت & فم & بابا \\
\hline نامى & قلم & ماء & عين & كرسى \\
\hline سكرى"الباب،" & ليمون & مخده & يد & تفاح \\
\hline سكرى"الثلاجه"، & بلوزة & ككه & عمو & سرير \\
\hline نادى على & بنطلون & تلفزيون & شعر & خز انة \\
\hline جييلى & حليب & مرجيحه & رأس & شنطة \\
\hline ارفعى بنطلونك & حديقة & كمبيوتر & أساور & سيارة \\
\hline افتحى الثلاجه & شاى & كلنس"محارم"، & عمرو & طاولة \\
\hline افتحى الباب & & محمد & ستارة & بابوج \\
\hline
\end{tabular}

As we can see, dual language learners can construct multiple lexicons and grammars even if the speakers or one of them is not a native speaker. Multilingual children do not merely acquire vocabulary. They rather construct multiple lexico-grammars. As stated earlier, multilingual children "develop separate, but related linguistic systems."

When I ask Joury - my third child aged now 2:6, for example, "Where is your hair?" she points to her hair, which means that she understands the structure as a question. This is a sign that she has grammaticalized this aspect of the interrogative system. When I give her something and ask her to put it on the table, she would take it and place it on the table. This shows that she has grammaticalized features of the imperative mood, understanding the utterance as a command or request. When her brother, Muhammad asks her, "Joury, where is the fan?," she would look in the direction of the ceiling fan and say, "up" - supporting that utterance with a semiotic gesture from her hand - a further sign of the development of aspects of nonverbal communication. When I ask her if she wants milk, she might say "No" if she does not feel like drinking milk or nod her head if she wants.

I was once dressed up ready to leave to my office. It had, however, become a daily ritual to give Joury every morning before departure a short ride around the neighbourhood. So on that morning, I asked Joury if she wanted to go to the playground - in front of our house with her brother Amr as usual. This was the exchange we had:

"Go to the playground?" I asked.

"No, car," she said, with a little tilt of her head.

This short exchange proves the workings of an emerging grammar or linguistic system. Joury correctly understood my sentence as a question to which her reply was "No". This negative 
rejoinder was further emphasized intersemiotically — using another semiotic system — with the tilt of her head, expressing disagreement, and expressly stating what she rather preferred "car." She desired a ride in the car. As for the playground, she could go to it after the ride.

Such instances indicate that the child's growing knowledge of the language goes beyond the mere acquisition of lexis. It is language as a whole with its many but finite interlocking systems or strata - sounds, words, structures, and discourse features. Such examples show the creative works of an emerging linguistic system under proliferation, alongside another or the other linguistic system (s) the multilingual child is being exposed to - Arabic in the case of my children.

Multilingual acquisition or the construction of multiple langues either simultaneously through the introduction of more than one language at the same time — or sequentially through the introduction of a second language after the first one has been introduced - is a marvel, a phenomenon that concerns linguists, language teachers, policymakers and should equally concern multilingual parents who or can speak fluently two languages or who can provide a bilingual environment for their children since birth.

Typically, this could be the case of a spouse of different extraction or even two spouses of the same origin but one is capable of speaking a foreign or a second language. This is also the case of immigrants residing in a country where the national language is different from their own first language or languages (L1 or L1s), e.g. Malaysia. This could also be the case of language teachers teaching a second or foreign language. In such settings and such households where there is richer and various linguistic input where people, ethnic groups, parents, maids and possibly grandparents, for example, have different or can speak more than one language, the question of multilingualism (language planning) - particularly early or simultaneous childhood multilingualism — should be a point of major concern.

It is significant to note here that even if there is only one human source, i.e. one parent or caretaker or mentor to interact with the child and expose him or her regularly to the second language, this will be sufficient for the child to acquire the second language he or she is being exposed to. My children, as noted earlier - whose chief source of English is me and whose sources of Arabic are their mother and the social milieu — are proficient in both Arabic and English. Note again that I am the primary personal source of English. So the fact that they can function well in English means that even if the source of a language is only one person, children will construct the system of such language. This will be the case as long as the source of the L2 input is proficient, regular and sufficient. Proficiency is tied up to the quantity, quality and diversity of input.

The dual language child will construct as part of their social semiotic as many systems as he or she is being exposed to, progressively and systematically going through such universal patterns or stages of (multilingual) acquisition and the development of pragmalinguistic competence - i.e. babbling or the baby's attempt to experiment with the range of sounds made possible by the human vocal apparatus and from which it makes a selection depending on what is heard around it, followed by the acquisition of nouns, followed by the vocabulary burst and construction of lexicogrammar(s), moving from holophrastic constructions to 
telegraphic ones, to fully grammatical sentences, to coherent and cohesive discourse - all in a miraculously short period of time.

Indeed, what children below the critical period need is exposure as noted. This is also applicable to school children. This fact demands from language teachers to be proficient in the second language they teach and to present it orally in the classroom, playing with children, rather than teaching formally.

Children acquire language intuitively from the ambient linguistic data. Learning at this age is implicit rather than explicit. Unlike adults, children below the critical period do not require explicit language instruction, but rather a need for sustained exposure/immersion to language in order to develop normally. Through long-term exposure - interaction and an immersive learning environment - children naturally observe, extract and internalize the lexicogrammar of a language or any number of languages effortlessly; and they carry out such creative active linguistic construction, or the expansion of their meaning potential, in a manner rapid, systematic, regular, and indeed effortless.

We should note in this context that multiple language learning or the acquisition of L2 depends on or is moderated by six specifics or variables - what is known as the Specificity Principle (SP) (McCabe et al., 2013: 5). These six specifics are: setting condition (e.g. isolated families vs immersive environments/degree of exposure to each language), person (e.g. male vs female or learner attitudes towards L2), language (degree of similarity between L1 and L2), time (e.g. younger vs older, or the duration of exposure), mechanism (e.g. formal vs informal), and outcome. Key to them all, however, is exposure. "As is the case for monolingual development, the rate of language development in multilingual children depends on the amount of language exposure in each language" (McCabe et al., 2013: 8).

Exposure is then the key to language development and ultimate attainment (AU) whether in L1 or L2. "Decades of research with monolingual children and more recent research with multilingual children have established that more language exposure results in more language learning" (McCabe et al., 2013: 4). Just like monolinguals, "studies of multilingual children indicate that the relative and absolute amounts of exposure to each language predict children's levels of vocabulary and grammatical development in each language" (ibid.). Proficiency - whether in L1 or L2 - is tied up to the quantity and quality of input parents or caretakers' responsiveness, conversational exchanges, interesting content, and diversity of speech in terms of lexis, syntactic structures and communicative functions (ibid.). Language input, therefore, plays an instrumental role in "the development of language of all children regardless of whether they are learning one or multiple languages" (ibid. p. 23).

\subsection{Practice and Policy Implications}

The policy implication of this for L2 pedagogy and practice is the need to make the daily language period at school for such multilingual skills to develop very tactile, very auditory, very visual - creating an immersive language environment. They need to incorporate and engage the learners' auditory, visual and experiential modalities for maximum engagement and learning efficacy. They need to engage learners in languaging. They need to tap in and 
capitalize on this inspired potentiality of learning, inquisitiveness for knowledge and this innate preparedness for language acquisition. In short, they need to create an immersive language environment.

What early childhood FL/SL teachers and classroom practitioners then need is a high level of proficiency, together with age-appropriate methodology skills. However, being lacking in communicative competence or the ability to communicate in the second language fluently themselves, and teaching it in the mechanical de-contextualized analytical Grammar-Translation rote-fashion where learners have to translate long lists of vocabulary, parse sentences, conjugate irregular verbs, etc., many language teachers deprive children of such exposure, crucial for language acquisition. Using traditional pedagogy deprives our children of the opportunity to acquire English or any other second/foreign language. This unfortunately results in school children leaving school, after 12 years of schooling, without developing even the minimal survival language proficiency as can be seen in many communities across the globe where English, for example, is being taught daily but ineffectively.

This deplorable state of affairs has to be changed. We have to teach English or any other second language in this case communicatively - teaching grammar and language for communication, for life, and not just as a mere body of rules that has nothing to do with life. Life is a constant flow of discourse - learning language is learning how to engage in discourse. People need to use language to fulfil needs, not just study it.

The best language teachers are, therefore, those who can speak another language themselves and those who can maximize exposure; who can present language orally in the classroom; who play with children; who recognize that language is a system - a socio-semiotic system of communication that serves major functions in human life, taught for the actual, genuine, spontaneous, and meaningful communication in L2; and acquired in the process of languaging. They view language as an activity learnt and mastered through a long developmental process of engaging in discourse (interpersonal interaction) and through meaningful engagement with interesting content (intrapersonal interaction). They view the development of L2 oracy or communicative competence as the ultimate goal of language teaching, and as a product of the progressive construction of a grammar and a lexicon; they recognize that the principal aim of teaching language to learners is to equip students with the ability "to communicate with each other fluently and effectively in the common diverse personal and professional situations of daily life" (Kharma \& Hajjaj, 1997), where the second language rather than one's own language, is to be used.

The best language teachers are those who recognize that oracy or the ability to engage in languaging fluently and grammatically starts with the ear - speech depends on hearing and so to develop listening and speaking skills, learners should be given the opportunity to hear English spoken and to speak it themselves, so that they can become fluent and accurate English speakers.

The best language teachers then present grammar and lexis in a listening context. They view language not as something that exists beforehand - an object that you buy or contemplate - 
but as something that one constantly constructs as one engages in languaging — we learn how to talk by talking, whether as children or as adults, in the continual semiotic process of learning to interact in a new world of discourse (a world with new or different sounds, different discrete units, different systems, different categories, different means, different signs, different collocations, different people, different media, different ways of languaging, different purposes). We learn when we actually interact in the world — the new world of discourse.

In short, the best language teachers are those who recognize that successful language learning depends on three elements: exposure to it in a variety of contexts, motivation to communicate with it, and opportunities to use it. A successful language teacher then is one who replicates these elements in the classroom, presenting language orally in the classroom, motivating students to communicate in the L2, and providing them with opportunities to practise it.

Children, therefore, should be given every possible opportunity to hear a second language spoken and to speak it themselves, so that they could become fluent and accurate multilingual speakers. We should ensure that pre-school caregivers and school L2 teachers who teach a second language are communicatively proficient themselves in the second language they are supposed to expose children to. Language teachers and classroom practitioners should engage in responsive conversations with children. They should maximize children's exposure to fluent input. Children require fluent input for language to develop normally. "In short, most of the lessons learned regarding optimal linguistic input to monolingual children apply to multilingual children: Children need to hear substantial amounts of responsive, positive, diverse, complex talk about objects and past events of interest to them" (McCabe et al. 2013: 7). Children's language is then "most supported when adults engage children in responsive, positive, varied, and complex talk about objects of interest to those children, past personal experiences, and books they are reading with them" (ibid. p. 14).

Children then need rich language experiences from loving caring human interactants. They need informal, long-term and enriched exposure. The implication again of this for caregivers and language teachers is that they should expose children to language informally in a context similar to that of the heritage language acquired at home. Teaching therefore should not be formal in these years of pre-schooling and schooling.

We should also develop and or identify multilingual programmes that expose these children to high-quality input in L2 during these years of pre-schooling and schooling (McCabe et al., 2013). L2 caregivers or babysitters and teachers as well parents can also make use of impersonal sources such as educational and entertaining YouTube videos that can engage children and expose them to L2 input. Frequently watching nursery songs and animated movies, along with storytelling and reading story books - "bookreading interactions" - are also beneficial multilingual platforms in this regard. Fortunately, development in multimedia semiotics and mass media technologies has made access and input to language rich and engaging. 


\subsection{Effects of Early Multilingualism}

Opponents of early multilingualism opine that simultaneous dual language learning right since birth is detrimental in three respects. First, it slows down or retards the learning of the first native language. Second, it would affect the child's cognitive development and his/her abilities of reading, arithmetic and other mental processes (Steinberg, Nagata \& Aline, 2001).Third; it would confuse the child and thus affect his/her mastery of either language due to the child's inability to distinguish between multiple different and complex emerging lexicons and grammars. Besides these speculations or reservations or (mis) conceptions levelled against early multilingualism is the fear of subtractive bilingualism, a case in which the child's native language may completely or partially get lost as another system begins to take hold when the child's L1 structures have not yet been fully mastered (Lightbown \& Spada, 1999).

Current research, however, "supports the idea that early, high quality exposure to multiple languages results in enhanced child language outcomes across each of the languages" (McCabe et al., 2013: 7-8). "Children who hear two languages from infancy start to learn both languages simultaneously, and the course of development in each language looks very much like the trajectory followed by monolingual children" (ibid.).

What then may sound or look for an adult as confusion is not as it actually seems. The multilingual child is actually aware of the presence and operation of two distinct or separate grammars and lexicons or operating systems (the separate systems [rather than unitary system] hypothesis) operating in his or her mind. Hence, when a multilingual child, in the course of speaking, code-switches among multiple linguistic codes, this should not be taken to signify confusion but rather the result of a lexical gap, which is but normal as the multilingual child who has multiple L1s to build, is certainly unlike and thus must not be viewed as "the monolingual child at a comparable stage of development" (Fromkin et al., 2011: 359). McCabe and colleagues (2013: 10) state that "uneven vocabulary knowledge is common for young dual language learners". They observe that "code-switching, or switching back-and forth between languages within an utterance or in the course of a conversation, is not a sign of confusion, but indicative of children's increased linguistic and cognitive control (Bhatt \& Bolonyai, 2011)" (ibid.).

Therefore, what may seem confusion to one is not really confusion. The multilingual child knows that he or she has more than one operating system; more than one language though they cannot tell at a young age that this is called English and this is Malay, for example. But when they make an utterance they know that it belongs to this system not the other. Children, being creative, just apply the principle of something better than nothing. So they code-switch not of what might appear to us as confusion but rather because of the presence of a semantic gap. Until that moment of their linguistic development, they haven't heard the word or syntactic system that would be used in that context. Therefore, instead of remaining silent, they borrow what they need from another linguistic system they already know to fulfill their communicative need - a sign of creativity and pragmatic competence rather than confusion. It is, as noted, a sign of children's increased linguistic and cognitive control. 
Translanguaging is then common and the multilingual child is aware of the multiplicity, distinctness and operation of the linguistic systems s/he is constructing and using in languaging or when engaging in discourse, but like most linguistic knowledge, this knowledge is intuitive or subconscious. However, though many "researchers stress the independence of languages" (Saville-Troike, 2006: 71), in terms of their structure and location in the brain, Ervin and Osgood (1954) suggest that there are three possibilities: multiple languages operating either independently of one another (coordinate bilingualism), or simultaneously (compound bilingualism), or dependently (subordinate bilingualism).

But the point to be stressed here is that regardless of the way of operating/languaging - i.e., whether independently, simultaneously or dependently - children know that when they use English, for example, that they are using English, rather than, say German and vice versa even when they cannot name the language they are using at a certain age. My experience and experiment with my own multilingual children (Muhammad, Amr and currently Joury) prove that. Therefore, regardless of the type of multilingualism, i.e. simultaneous or sequential, or the way of operating, i.e., independently, simultaneously or dependently, and the setting of learning, multilingual children recognize that they have multiple distinct linguistic systems (under construction/operation). Actually, metalinguistic awareness - which refers to a speaker's conscious awareness about language rather than of language (Fromkin et al., 2011: $361)$ - is one of the distinct advantages immediately linked to multilingualism.

I would like to add in this context what Amr - my second bilingual of Arabic and English child - who once went on laughing heartily when his chiefly monolingual Arabic-speaking mother asked him if he wanted to have some "yoghurt," using in her verbal exchange with him the untypical English word, instead of the Arabic. Amr (at age 2; 3 at the time) was very amused that his mother used the English word "yoghurt," which was uncharacteristic of his Arabic-speaking mother, saying with a chortle of delight: "Daddy yoghurt, Daddy yoghurt". In other words, the child's amusement was because he did not expect that utterance (yoghurt) to come from his Mummy (the Arabic linguistic system, in other words). It was obvious that he equated "yoghurt" with another linguistic source (that of his Daddy/that of English).

This empirical specimen emphasizes the point I am making, that young L1ers who are in the creative process of constructing multiple lexicons and grammars are aware of the presence and operation of multiple languages. This shows that when a child resorts to translanguaging or code-switching, he or she is not confusing linguistic systems but rather making use of whatever semiotic resources are available at their disposal.

Multilingualism then raises metalinguistic awareness - a speaker's conscious awareness about language rather than of language. While a bilingual Arabic-English child, for instance, say "I speak Arabic and English," a monolingual Arabic child would likely say: "What's Arabic?". In the words of McCabe and colleagues (2013:9):

There is a large body of work that suggests that being multilingual fosters children's ability to think about language per se, leading to increased metacognitive and metalinguistic skills (Bialystok, 2007). Recent brain research indicates that multilinguals have greater brain tissue density in the 
areas of the brain related to language, memory, and attention, with the highest levels of tissue density among those who were exposed to a second language prior to age 5 (Mechelli et al., 2004).

In other words, a multilingual person is not just like having two monolingual heads in one head, cognitively speaking. Early multilingualism, causes physical differences in the structure or anatomy of the brains of children receiving more than one language, a process shaped or aided by brain plasticity in infancy or the early years of life. Multingualism has then proven effects on the physical or anatomic structure, growth or tissue density, and functions of the brain. Such differences lead to emerging individual differences. Multilingual children have more brainpower than their monolingual counterparts. "L2 users have different cognitive processes" (Saville-Troike, 2006, 8). Their conceptualization, rationalization and imagination or imagining of the world is different; the way they look at or perceive things is different; it is richer; it is deeper; it is multifold.

It is significant in this connection to note that multilingualism is not only beneficial to children but to adults too. As adults, or towards the other end of life, multilingualism has been associated, amongst other factors, with the prevention or delay of dementia or mental decline, which makes multilingual speakers to have a clear edge over their monolingual counterparts throughout their lives.

Taking into account such encephalic or cortical structural differences of multilinguals vis-a-vis monolinguals, speaking more than one language regularly leads to the activation of more parts or areas in the brain. This bigger volume of brain usage or regular exercise strengthens different parts of the brain. This leads multilingual speakers to have better complex cognitive skills such as "planning, working memory, mental flexibility, and many other important functions" (Bialystock, n.d.) - factors or advantages found to protect against or delay the onset of certain types of mental or memory diseases such as dementia, senescence and Alzheimer's.

Research in this area has since the 1960s stressed the positive cognitive effects of multilingualism or the early exposure to multiple languages on intellectual functions effects such as "conceptual development, creativity, metalinguistic awareness, semantic development, and analytic skills" (Bialystock, Craik, Green, \& Gollan, 2009; Cook, 1992; Diaz, 1985). These results are also reported by Fromkin and colleagues (2011) who state that the "results of...recent research indicate that bilingual children outperform monolinguals in certain kinds of problem solving" (361). Fromkin and colleagues (ibid.) further observe that "bilingual children have an earlier understanding of the arbitrary relationship between an object and its name" - the symbolic or arbitrary relationship between the signifier and signified. In fact, according to McCabe and associates (2013), "many authors (e.g., García, 1983; Rogler, Cortes, \& Malgady, 991) have speculated that individuals who have the ability to switch between two or more languages also exhibit higher cognitive functioning and mental health status" (10).

The cognitive effects of multilingualism are undeniable. Multilingualism has distinct positive intellectual advantages — the intellectual edge that multilingual children have over their 
monolingual counterparts is a reality. Multilingualism is then more than just having multilingual competence as far as communication skills and the expression of language functions in different social milieux is concerned.

Cook (1992: 557), therefore, states that cognitively, these "subtle differences consistently suggest that people with multicompetence are not simply equivalent to two monolinguals but a unique combination." They conceptualize things and the world differently and so perform cognitively as a result differently. Multilinguals perceive and experience the world through more than one socio-semiotic or cultural lens. Multicompetence, is therefore, "a different state of mind" (ibid.).

Lightbown \& Spada (1999:4), therefore, conclude that children who get the opportunity to learn a number of languages from infancy and to maintain them throughout their lives "are fortunate indeed," and parents or households or nations that can offer such opportunity to their little ones should by all means do so.

Last but not least, multilingualism or "speaking more than one language is often an entry card for the global economy" (McCabe et al., 2013: 3). As we noted in the introduction, "What language/s you speak is one way in which you immediately have access to, or excluded from, some kinds of power" (Thomas and colleagues, 2004: 12).

Multilingualism is common, stable and increasing. Half of the world population is bilingual where such people are native speakers of two or more languages. It is not an individual phenomenon - individual bilingualism. Multilingual practice is a societal phenomenon in many societies where the circumstances permit and where value of multilingualism is perceived - societal bilingualism. Reporting on the current situation, Tucker (1999) concludes:

There are many more bilingual or multilingual individuals in the world than there are monolingual. In addition, there are many more children throughout the world who have been and continue to be educated through a second or a later-acquired language, at least for some portion of their formal education, than there are children educated exclusively via the first language (1).

\section{Conclusions}

Within the context of the centrality of language to our life and relations, existence and coexistence, enlightenment and mystification, peace and war, domination and emancipation, socialization and acculturation, etc., this paper reflected upon the origin and diversification of language - pointing to a divine origin - its centrality and functionality in human existence, and nature of acquisition before paving the way to the undeniable merits of the favourable introduction of early multilingualism as a big thing that deserves and demands serious attention - on the part of multilingual parents, ELT practitioners, second/foreign/other language teachers, language methodologists and policy makers.

What the paper stressed as immediate advantages of being exposed to multiple languages in the early years of life are the effortless acquisition and the native-like proficiency in language 
processing when communicating. These advantages - the unselfconscious ease with which children rather than adults acquire language, and the child-like subconscious automaticity in language processing - disappear when learning language as an adult for language learning then requires explicit instruction — and so effort and attentiveness.

Moving from a caterpillar to a butterfly, from prelinguistic communication (what Halliday calls "protolanguage") to communicative competence (language), child language development or the child's innate drive to socialize to construct language (s) is a phenomenon we should capitalize on. Encouraging childhood multilingualism, the paper stated that children not only have a prodigious innate aptitude for constructing multicompetence in whatever languages they regularly get exposed to, and in a manner so rapid, so creative, and indeed so easy compared with the mammoth task that they, within a short time, accomplish triumphantly, but also emphasized the distinct and many cognitive advantages or intellectual edge of multilinguals over their monolingual peers.

The paper encourages multilingual parents and families who have the ability to bring up their children as bilingual or multilingual not to forgo this golden opportunity but rather capitalize on it. What may seem confusion to one, the paper illustrated, is not really confusion, but rather a sign of creativity and pragmatic competence; a sign of the child's increased linguistic and cognitive control.

Children can acquire any number of languages with the same rapidity, systematicity, and facility regardless of the number of languages they may be exposed to or constructing at the same time. So long as there is a regular linguistic source, children will acquire any language or number of languages and develop multicompetence. There is just a need for being regular and systematic, providing sustained language input. You use, for example, English all the time, your spouse, let's say, Arabic, a maid in the house, Tamil or Tagalog, a grandfather, Hebrew or Russian, etc. As long as there are regular sources, as long as each person communicates regularly in one semiotic or linguistic source, multilingual children will acquire all these semiotic systems or multiple languages with the same innate drive, divine mechanism, and effortlessness and joy.

The study has illustrated that multilingualism is not only highly desirable and possible without any detriment of any kind, but also very positive. The paper has highlighted the need to view having more than one language — multilingualism — as a strength and great plus without any risks being involved concerning the development of the home or heritage language. "If dual language input is maintained, multilingual children can perform on par with monolingual children in both languages by the age of 10 years" (McCabe et al., 2013: 8). "In fact, there is strong evidence to suggest that when children are reared in a high-quality language environment where both L1 and L2 are valued and used in an ongoing way, learning multiple languages has cognitive, social, and potentially economic benefits" (ibid.).

I have drawn upon multilingualism research and used the empirical evidence of my own children to illustrate that young children indeed can learn multiple languages with no issues and that early multilingualism enhances children's "cognitive functioning and mental health," communication skills, literacy skills development, semantic development, "increased 
metacognitive and metalinguistic skills" (Bialystok, 2007), creativity, "high academic achievement and positive personality adjustment" (McCabe et al., 2013: 10), phonemic awareness, and is related to greater conceptual and cognitive flexibility in life. In a word, multiple language learning is not a zero-sum game, but rather a win-win situation. Under supportive contexts, "children can become fluent in two languages and reap the benefits of dual-language skills" (McCabe et al, 2013: 14).

In the context of language teaching and learning, the study, in light of such discussion, calls upon second language teachers to recognize their responsibility and crucial role in tapping into the child's divine potentiality of learning and innate preparedness for the effortless construction of this feat in the early and childhood years of our little ones; emphasizing that the best language teachers are then those who recognize that successful language learning depends on long-term and enriched exposure to it, motivation to communicate with it, and opportunities to use it in a variety of contexts. And so a successful language teacher is then one who replicates these elements in the classroom, presenting language orally in the classroom, in a manner similar to L1; motivating students to communicate in the L2; and providing them with opportunities to practise it. And so the study stresses that the implication of this for L2 pedagogy and practice is the need to make the daily language period at school very tactile, very auditory, very visual — creating an immersive language environment.

\section{References}

Aitchison, J. (1999). Linguistics: An Introduction (5 ${ }^{\text {th }}$ ed.). UK: Hodder \& Stoughton.

Aitchison, J. (2003). Linguistics (6 ${ }^{\text {th }}$ ed.). UK. Teach Yourself.

Amer, M. M. (2009). 'Telling-it-like-it-is': the delegitimation of the second Palestinian Intifada in Thomas Friedman's discourse. Discourse \& Society, 20(1), 5-31.

Badi, J., \& Tajdin, M. (2005). Creative Thinking: An Islamic Perspective. Kuala Lumpur: IIUM Press.

Bialystock, E. (n. d). Would you learn a new language if it would help your health? Retrieved July 2, 2013, from hotword.dictionary/dementiaprotection/

Bialystok, E., Craik, F. I. M., Grady, C., Chau, W., Ishii, R., Gunji, A., \& Pantev, C. (2005). Effect of bilingualism on cognitive control in the Simon task: evidence from MEG. NeuroImage, 24(1), 40-49. https://doi.org/10.1016/j.neuroimage.2004.09.044

Bialystok, E., Craik, F. I. M., Green, D. W., \& Gollan, T. H. (2009). Bilingual Minds. Psychological Science in the Public Interest, 10(3), 89-129.

Bickerton, D. (2009). Adam's Tongue: How Humans Made Language, How Language Made Humans. New York: Hill \& Wang.

Brown, H. D. (2000). Principles of Language Learning and Teaching (4 ${ }^{\text {th }}$ ed.). New York: Addison Wesley Longman, Inc.

Chomsky, N. (1965). Aspects of the Theory of Syntax. The MIT Press: Cambridge. 
Chomsky, N. (1993). A minimalist program for linguistic theory. MIT Occasional Papers in Linguistics no. 1. Cambridge, Massachusetts.

Chomsky, N. (1994). The Human Language Series. Programme 2.

Chomsky, N. (2006). Language and Mind ( $3^{\text {rd }}$ ed.). Cambridge: Cambridge University Press.

Cohn, C. (1987, June). Slick 'ems, glick' ems, Christmas trees and cookie cutters: nuclear language and how we learned to pat the bomb. Bulletin of Atomic Scientists, 43, 17-24.

Cook, G. (2003). Applied Linguistics. Oxford: Oxford University Press.

Cook, V. (1992). Evidence for Multicompetence. Language Learning, 42(4), 557-91.

Crystal, D. (2003). English as a Global Language (2 ${ }^{\text {nd }}$ ed.). UK: Cambridge University Press.

Diaz, R. M. (1985). The intellectual power of bilingualism. The Quarterly Newsletter of the Laboratory of Comparative Human Cognition, 7, 16-22.

Ervin, S. M., \& Osgood, C. E. (1954). Second language learning and bilingualism. Journal of Abnormal and Social Psychology, 58, 139-45.

Fairclough, N. (2001). Language and Power ( $2^{\text {nd }}$ ed.). London: Longman.

Fairclough, N. (2003). Analysing Discourse: Textual Analysis for Social Research. London: Routledge.

Firth, J. R. (1968). Selected Papers of J. R. Firth.1952-1959, (F. R. Palmer, Ed.). London: Longman: Longman Linguistic Library.

Fromkin, V., Rodman, R., \& Hyams, N. (2011). An Introduction to Language (9 ${ }^{\text {th }}$ ed.). Canada: Wadsworth, Cengage Learning.

Halliday, M. A. K. (1975). Learning How to Mean: Explorations in the Development of Language. London: Edward Arnold.

Halliday, M. A. K., \& Matthiessen, C. M. I. M. (2004). An Introduction to Functional Grammar ( $3^{\text {rd }}$ ed.). London: Arnold.

Harris, R., \& Taylor, T. J. (1989). Landmarks in Linguistic Thought: The Western Tradition from Socrates to Saussure. London and New York: Routledge.

Jaworski, A., \& Coupland, N. (1999). The Discourse Reader. London: Routledge.

Johnstone, B. (2002). Discourse Analysis. Oxford: Blackwell.

Khan, A. (n. d.). Theories of the early stages of language acquisition. Retrieved August 25, 2019, from https://www.khanacademy.org/test-prep/mcat/processing-the-environment/language/a/theorie s-of-the-early-stages-of-language-acquisition

Kharma, N., \& Hajjaj, A. (1997). Errors in English among Arabic Speakers: Analysis and Remedy. Beirut: York Press Libraire du Liban Publishers. 


\section{INacrothink}

Kreidler, C. W. (1998). Introducing English Semantics. London: Routledge.

Lightbown, P. M., \& Spada, N. (1999). How Languages are Learned (2 ${ }^{\text {nd }}$ ed.). Oxford: Oxford University Press.

McCabe, A., Tamis-LeMonda, C. S., Bornstein, M. H., Cates, C. B., Golinkoff, R., Hirsh-Pasek, K., ... Guerra, A. W. (2013). Multilingual children: Beyond myths and towards best practices. Society for Research in Child Development Social Policy Report, 27(4).

Phillipson, R. (1992). Linguistic Imperialism. Oxford/New York: Oxford University Press.

Rozakis, L. E. (2003). The Complete Idiot's Guide to Grammar and Style (2 ${ }^{\text {nd }}$ ed.). USA: ALPHA.

Saville-Troike, M. (2006). Introducing Second Language Acquisition. Cambridge: Cambridge University Press.

Simpson, P. (1993). Language, Ideology and Point of View. London and New York: Routledge.

Steinberg, D. D., Nagata, H., \& Aline, D. (2001). Psycholinguistics: Language, Mind, and World ( $2^{\text {nd }}$ ed.). Harlow, England: Longman.

The Holy Qura'an: An eternal translation of the great book of the Universe. Retrieved, August 26, 2019, from http://mquran.org/content/view/4905/4/

Thomas, L., Wareing, S., Singh, I., Peccei, J. S., Thornborrow, J., \& Jones, J. (2004). Language, Society and Power: An Introduction ( $2^{\text {nd }}$ ed.). USA and Canada: Routledge.

Tucker, G. R. A global perspective on bilingualism and bilingual education. ERIC Digest. Washington, DC: ERIC Clearinghouse on Languages and Linguistics.

Van Dijk, T. A. (1992). Discourse and the Denial of Racism. Discourse \& Society, 3(1), 87-118.

Widdowson, H. G. (1992). Practical Stylistics. Oxford: Oxford University Press.

Wodak, R., \& Meyer, M. (2009). Critical Discourse Analysis: History, Agenda, Theory and Methodology. In R. Wodak, \& M. Meyer (Eds.), Methods of Critical Discourse Analysis $\left(2^{\text {nd }}\right.$ ed., pp. 1-33). London: Sage.

Yule, G. (2010). The Study of Language ( $4^{\text {th }}$ ed.). Cambridge: Cambridge University Press. 


\section{About the Author}

Aladdin Assaiqeli holds a master's degree in TESL and a doctorate in Applied Linguistics from International Islamic University Malaysia. He has taught ESL/EFL and linguistics at Ajman University of Science and Technology, UAE; Dhofar University, Sultanate of Oman; Al-Aqsa University, Palestine; and the International Communication Academy, Malaysia. He is currently teaching at Sultan Idris Education University (UPSI), Malaysia. His research interests include L2 learning and teaching, language acquisition, critical discourse analysis (CDA), visual communication, and the Palestine Question. [Email: assaiqeli@gmail.com]

\section{Copyrights}

Copyright for this article is retained by the author(s), with first publication rights granted to the journal.

This is an open-access article distributed under the terms and conditions of the Creative Commons Attribution license (http://creativecommons.org/licenses/by/4.0/) 